\title{
Pioneering political ecology: perceptions of nature, Indigenous practices and power relations during Alexander von Humboldt's travels in Latin America
}

\author{
Joachim Eibach ${ }^{1}$ \\ Tobias Haller \\ University of Bern, Switzerland
}

\begin{abstract}
This article is an attempt to discuss the image of Alexander von Humboldt as a pure natural scientist with a humanist ethos, and to highlight that he was in fact one of the first thinkers who anticipated positions known today as political ecology. We outline that his universal knowledge obviously has contradictory perspectives, and was interpreted in several directions. On the one hand, there is the position taken by post-colonial critics that Humboldt showed Eurocentric and imperialist thinking during his travels to the Americas, as Pratt has advocated. On the other hand, and in explicit contrast to the post-colonial critique, Humboldt has been regarded by Sachs as a founding figure of American environmentalism and as "perhaps, the first ecological thinker." Furthermore, Wulf's biography titled The Invention of Nature tries to show that Humboldt wanted to bridge the gap between the emerging natural sciences and Romanticist aesthetics. However, based on his writings, we argue that his perception of nature has been misread and that his position was shaped by a view akin to open and critical political ecology, as opposed to pure nature constructivism without including local humans. We show this by focusing on his research methods that were open to local Indigenous ecological knowledge, his appraisal of Indigenous socio-cultural systems, his perception of nature as Indigenous cultural landscapes degraded by colonial and early capitalist market forces, his openness towards Indigenous ontologies of what we call nature, and finally his focus on local institutions for the sustainable governance of resources.
\end{abstract}

Key Words: Political ecology, Alexander von Humboldt, anthropology, human-environment interactions, power relations, institutions, colonialization, Indigenous practices

\section{Résumé}

Cet article tente de discuter de l'image d'Alexandre von Humboldt en tant que pur scientifique naturel avec une philosophie humaniste et de souligner qu'il a en fait été l'un des premiers penseurs à anticiper des positions connues aujourd'hui sous le nom d'écologie politique. Nous soulignons que sa connaissance universelle a évidemment des perspectives contradictoires et a été interprétée dans plusieurs directions. D'une part, il y a la position des critiques postcoloniaux selon laquelle Humboldt a montré une pensée eurocentrique et impérialiste lors de ses voyages aux Amériques, comme Pratt l'a préconisé. D'un autre côté, et contrairement à la critique postcoloniale, Humboldt a été considéré par Sachs comme une figure fondatrice de l'environnementalisme américain et comme "peut-être le premier penseur écologique». En outre, la biographie de Wulf intitulée The Invention of Nature tente de montrer que Humboldt voulait combler le fossé entre les sciences naturelles émergentes et l'esthétique romantique. Cependant, sur la base de ses écrits, nous soutenons que sa perception de la nature a été mal interprétée et que sa position a été façonnée par une vision proche de l'écologie politique ouverte et critique par opposition au constructivisme de la nature pure sans inclure les humains locaux. Nous le montrons en nous concentrant sur ses méthodes de recherche ouvertes aux connaissances écologiques autochtones locales, son appréciation des systèmes socioculturels autochtones, sa perception de la nature en

\footnotetext{
${ }^{1}$ Dr. Joachim Eibach, Associate Professor, Department of History, University of Bern, Switzerland. Email: joachim.eibach "at" hist.unibe.ch. Dr. Tobias Haller, Professor, Institute of Social Anthropology, University of Bern, Switzerland. Email: tobias.haller "at" anthro.unibe.ch. The authors thank Enrique Corredera Nilsson and Maximilian Lederer for their important comments on earlier versions of this article and support in researching relevant sources on the work of Alexander von Humboldt. Thank you also to the referees.
} 
tant que paysages culturels autochtones dégradés par les forces du marché colonial et capitaliste précoce, son ouverture aux ontologies autochtones de ce que nous appelons « la nature » et enfin son focus sur les institutions locales pour une gouvernance durable des ressources.

Mots-clés: Écologie politique, Alexander von Humboldt, anthropologie, interactions homme-environnement, relations de pouvoir, institutions, colonialisation, pratiques autochtones

\section{Resumen}

Este artículo es un intento de discutir la imagen de Alexander von Humboldt como un científico natural puro con un espíritu humanista y resaltar que, de hecho, fue uno de los primeros pensadores que anticipó posiciones conocidas hoy como ecología política. No obviamos que su conocimiento universal obviamente tiene perspectivas contradictorias y ha sido interpretado en varias direcciones. Por un lado, está la posición de los críticos poscoloniales de que Humboldt mostró un pensamiento eurocéntrico e imperialista durante sus viajes a las Américas, como ha defendido Pratt. Por otro lado, y en explícito contraste con la crítica poscolonial, Sachs ha considerado a Humboldt como una figura fundadora del ambientalismo estadounidense y como "quizás, el primer pensador ecológico." Así mismo, la biografía de Wulf titulada The Invention of Nature intenta mostrar que Humboldt quería cerrar la brecha entre las ciencias naturales emergentes y la estética romántica. Sin embargo, basándonos en sus escritos, argumentamos que su percepción de la naturaleza ha sido mal interpretada y que su posición fue moldeada por una visión similar a la ecología política abierta y crítica en oposición al constructivismo de la naturaleza pura sin incluir a los humanos locales. Mostramos esto centrándonos en sus métodos de investigación abiertos al conocimiento ecológico indígena local, su valoración de los sistemas socioculturales indígenas, su percepción de la naturaleza como paisajes culturales indígenas degradados por las fuerzas del mercado colonial y capitalista temprano, su apertura hacia las ontologías indígenas de lo que nosotros entendemos por naturaleza y finalmente su interés en las instituciones locales para la gobernanza sostenible de los recursos.

Palabras clave: Ecología política, Alexander von Humboldt, antropología, interacciones humano-medio ambiente, relaciones de poder, instituciones, colonialización, prácticas indígenas

\section{Introduction}

In recent decades, the image of Alexander von Humboldt in general, and the assessment of his writings, have experienced several shifts. From the late $19^{\text {th }}$ century, Humboldt was primarily seen as a natural scientist with a humanist ethos. He was regarded as the last person to hold universal knowledge. This solid and rather uniform interpretation has given way to different and partly contradictory perspectives. The term 'Humboldtian science', coined by Susan Faye Cannon, points to practices of accurate observation and measurement, encyclopaedic knowledge and numerical expression, combined with an equilibrium model of nature (Dettelbach 1996). Post-colonial critics have argued that during his travels through Spanish America, Humboldt relied on the colonial infrastructure and never overcame Eurocentric and imperialist attitudes. Hence he delineated landscapes in which native inhabitants were absent (Pratt 1992). However, in explicit contrast to the postcolonial critique, Humboldt has been regarded as a founding figure of American environmentalism and as "perhaps, the first ecological thinker" (Sachs 2003, 114; Sachs 2006). The fact that Humboldt's views on nature sought to bridge the gap between the emerging natural sciences and Romanticist aesthetics was taken by Andrea Wulf as the underlying idea of her biography, titled The Invention of Nature (2015). In fact, this title reflects the challenges that exist when discussing Humboldt's views, as we will show by arguing that his aim was to understand nature-human interactions rather than to invent what has since been labelled as 'nature.'

Humboldt's attempts to gather as much knowledge as possible and to combine different types of knowledge - formerly understood as an antiquated idea pointing backwards to early modern scholarship and outdated by the mid- $19^{\text {th }}$ century - is now actually seen as an innovative, trans-disciplinary and inter-connected approach of "think science interconnected" (German: Wissenschaften zusammendenken) in a global perspective (Ette 2009; Kviat Bloch, Lubrich and Steinke 2021). Moreover, not just sciences originating in the $19^{\text {th }}$ century such as geography and botany, but also academic disciplines of more recent origin like climatology and ecology, are methodologically rooted in the writings of Humboldt. In addition, anthropology (today labelled as social anthropology, cultural anthropology or ethnology) fits into this category. Humboldt did not write a single 
ethnography on the Indigenous groups of Latin America, although his works include numerous pages, sections and chapters on Indigenous practices and beliefs, collected in the field in a manner that may be called socialanthropological avant la lettre (Lubrich 2009; 2019). Humboldt's notion of 'anthropogeography of the Cosmos' had a far-reaching impact on the emerging sciences, both in Germany and America (Bunzl 1996). Furthermore, as we will demonstrate in this article, Humboldt must be seen as one of the first environmental scientists to critically observe human-environment interactions and to realize that power relations between humans are a strong driver of environmental change. He is also mentioned in a textbook on political ecology (see Robbins 2004) as a scholar with early reflections in that field. Nevertheless, as we will argue below, Humboldt's legacy for newer strands of political ecology needs further discussion.

Thanks to the $250^{\text {th }}$ anniversary of Humboldt's birth in 2019, not only has public interest in this remarkable scholar grown to new heights, but numerous texts by Humboldt, hitherto never published in a modern edition, have been discovered or rediscovered. As a result of meticulous research, a ten-volume edition edited by Oliver Lubrich and Thomas Nehrlich contains and comments on all the texts that Humboldt authored and that went into print during his lifetime, except for his monographs (Humboldt 2019). This article will rely on Humboldt's published travel reports, entries in his travel diary and the source material of this new edition.

\section{From anthropology to political ecology}

To date, the different readings of Humboldt's works as outlined above have somehow failed to grasp a relevant aspect of the interconnectedness of his thinking. It is puzzling that so far - despite being discussed by Lubrich and others - Humboldt's relation to anthropology at large (including elements from today's different orientations such as social anthropology, cultural anthropology or ethnology) and also his environmental and interrelated political views have largely been overlooked. Today we relate Humboldt's interest in local people to anthropology because he was concerned with emic (internal) perspectives and cultures. However, he also showed deep interest in the political interpretations of potential transformation processes in the so-called environment, a perception more typical of political ecology. In this combination of multidisciplinary views, the main issue we focus on here is his understanding of multiple actor orientations and power relations, which have remained hidden behind the gaze of his 'landscape called nature.' We try to link Humboldt's perspectives on nature as a landscape, with local and other actors. Behind what might initially appear as scenic, pure nature in Humboldt's reports are specific interests, his knowledge of different backgrounds, and specific historical interactions.

While reading Humboldt's many texts on his journey in Latin America, it becomes evident that he was interested not only in what he regarded as the overwhelming beauty of 'nature' and/or its interrelatedness viewed from the perspective of the natural sciences. Time and again he also focused on two other issues, which were very different from the mainstream thinking of his time. First, he was interested in local Indigenous interactions with, and views about 'nature', as European science called it at that time. He persistently indicated that it was worth including local Indigenous viewpoints and he saw value in these perspectives. He also drew comparisons between great cultural achievements in Europe and Indigenous equivalents in other parts of the world. Second, he had a genuine political view on regional histories. He realised that colonial history paved its way through the landscape, which was not therefore 'natural', and left its marks. Accordingly, it was not just slavery, racism and exploitation in general terms that captured his attention and against which he positioned himself; his perceptions and observations of the landscape itself were guided by being attentive to the specific impacts of colonial processes. Humboldt was a pioneer of what would later be labelled political ecology.

What does the term 'political ecology' mean and imply? As interest in ecological research grew during the 1970s and 1980s, challenging the view that environmental destruction results largely from population increase and destructive practices, exploiting natural capital beyond replenishment rates. What was lacking behind the ecological critique of industrial and post-industrial society was an analysis of the power dynamics shaping degradation. Two of the first authors to examine this issue were Blaikie and Brookfield with their important work on the causes of processes of land degradation. In Land Degradation and Society (1987), they clearly outlined that soil erosion is not a natural process but that those actors who cause soil erosion in some contexts do so because they face challenges from less proximate forces. If land users are poor or made poor, 
and do not have access to sufficient resources, they are forced to degrade the environment in which they find themselves in order to make a living. Subsequent degradation is not merely based on local users' ignorance, but on historical processes of land alienation and inequality. The overuse of ecosystems by the workings of unequal power relations does not simply unfold among small-scale resource users, but rather is connected to how more powerful corporate and state actors gain access to land, alienating the poorer and less powerful in the process. Over time, land or other resources are used more intensively and subsequently degrade. Zimmerer and Bassett (2003) and Robbins (2004) present this as a Marxian strand of political ecology. There are parallels with scholars working on common property, who argue that resource rights and access to resources are often appropriated by more powerful actors, leading to enclosure and the overuse of remaining resources (Brockington et al. 2008; Haller 2010, 2019).

A second Foucauldian, constructivist strand in political ecology interrogates discourses and narratives, particularly looking at who controls them. Who has the power to define, and with what labels (Haller 2019)? The ideology of so-called 'pure nature' or 'wilderness' is applied to landscapes that are far from pristine or devoid of people, to justify saving them from local people. The protection of nature therefore requires excluding local people (fortress conservation) or permitting some development activities outside protected areas (a comanagement approach, see Brockington et al. 2008, and Haller and Galvin 2011 on a critical stance to participatory approaches in conservation). This strand of political ecology notes that more powerful external actor groups (government agencies, donors, conservation organisations, etc.) try to define in a hegemonic way what a non-destructive use of nature is, simultaneously undermining the legitimacy of local actors remaining in place, and in the process devising a specific sustainable development narrative (ibid.). Examples include the power to define a forest as an endangered pristine place, or naming a savannah landscape as being the result of degradation caused by local people. Fairhead and Leach (1996) showed that savannahs in Guinea, West Africa, were not actually created by local people due to their overuse of the forests, as the narrative dating from colonial times asserted. Rather, forest islands in the savannah were created, extended and maintained by local actors.

This then leads to a third, newer strand in political ecology, which is interested in the ontologies and epistemologies of the power relations that operate in a male and Western human-centred view of the world. It accompanies a feminist stance and recognition of Indigenous views (totemism and animism) concerning what we call 'nature', as an entity that does not only include humans but also non-humans (animals, plants, etc.) as interrelated active spiritual beings or 'actors' that have an influence on living people (see also Escobar 1999; Descola 2013). This version of political ecology observes power dynamics, which are male and human-centred dominated, but its feminist or Indigenous stance on power reveals a different critical view of mainstream political ecology (for a more extensive summary, see Svarstad et al. 2018; Haller 2019).

While the second and third strands stem from the critique of the first (and sequentially, the second), we argue that a combination of these three versions of power relations, analysed in terms of political ecology, proves fruitful. Interestingly, Humboldt's reports on Latin America encompassed them all. As we will demonstrate, he was interested in what today might be called classical power relations in the context of exploitation and expropriation as the cause of environmental degradation. However, he was additionally critical of the view that the landscapes he encountered were purely natural, free of pre-colonial humans. He saw that the construction of this void served as the ideological basis for environmental alienation and destruction. He was interested in the views and practices of local Indigenous peoples and their genuine views, including incorporation of non-human actors in what the Western world perceived as 'nature.' Although he recognised that these perspectives were different from those in Europe at the time, which was dominated by scholars of the Enlightenment or upcoming Romanticism, he maintained the position that non-Western viewpoints needed to be heard and considered, due to the important information they could contribute to holistic understanding. Last but not least, he interacted closely with Indigenous groups to develop a fuller understanding of their thinking. Sometimes Humboldt crossed socio-cultural borders in order to obtain precise, differentiated and allencompassing knowledge, which was his ultimate objective. This is evident from the methods he used in situ, his appraisal of Indigenous cultures and knowledge and his analysis of degradation, markets and power relations during his time. Humboldt simultaneously used colonial language and reflected critically on its underlying ideology. Crucially, his views were not only embedded in norms of justice and humanism, but may be seen as path-breaking with regard to what would later be called political ecology. 


\section{Humboldt's methods, and his appraisal of Indigenous socio-cultural systems}

When Humboldt debarked from the frigate Pizarro in New Granada (Venezuela) on 16 July 1799, he was familiar with the manifold discourse of the era of the European Enlightenment as it related to the Americas. However, what he and his companion Aimé Bonpland encountered on their long journey across the Llanos, on the River Orinoco, over the Andes and in Mexico and Cuba all too often deviated from that discourse. Having a botanist background and being a trained mining engineer, Humboldt was accustomed to applying empirical methods. Moreover, being an adherent of the ideas of the French Revolution, he was not blind to the political and economic interests of powerful actors. Rather than trusting in philosophical ideas of a natural state of primitive hordes, or in a stadial theory of the history of humankind, Humboldt took to counting, measuring and observing what he saw on the spot. Clearly, he strove for the highest possible accuracy and differentiation, thereby applying the scientific methods of his time. In addition - and in contrast to his scientific peers, most of whom never travelled to countries outside Europe - he took every opportunity to communicate with local actors regardless of their background: colonial administrators and missionaries, members of the creole elites, villagers and hacienda dwellers, Indigenous peoples converted to Christianity by force in missions, and 'free Indians' living in the bush beyond the control of colonial institutions. Humboldt spoke Spanish fluently. He used local guides, tillermen and carriers, many of whom had knowledge of Spanish. However, he explicitly advocated that future travellers talk to Indigenous people without interpreters. Indeed, direct communication, even the use of sign language, would be "more instructive and more secure" (plus instructifs et plus sûrs) than unmotivated interpreters. Moreover, it gave the Indigenous respondent a feeling of being appreciated (Humboldt 1970, 2: 278).

Humboldt did not hide from direct contact with native people. During their two-and-a-half-month boat trip on the Orinoco, he and Bonpland spent the nights in hammocks or on the ground around the fireplace with their scullers (ibid. 251). Humboldt let his Indigenous interlocutors use his precious instruments (for instance his compass, a sextant with binoculars and a chronometer) and recorded their reactions (Humboldt 2003, 199). He carried a completely surprised local sillero (porter) used to carrying colonial elites over the mountain passes of the Colombian Andes on his back, across a room in order to find out how the process worked (ibid., 222224). In sometimes dubious ways, Humboldt crossed cultural and religious borders. On some occasions he asked more of his guides than they were able or willing to give, as will be delineated in greater detail below. At the same time, he was ready to push himself beyond limits, whenever it seemed necessary to expand his knowledge. In order to explore native skills, he included himself in experiments. For example, he painted his skin with the typical red color of the Indigenous tribes to find out if it provided protection against the plague of mosquitos (Humboldt 1970, 2: 261). Fascinated by the fact that the natives could identify a tree species from the taste of its bark, he put the barks of fifteen different trees in his mouth, albeit without recognising any difference (Humboldt 2003, 181). According to his essay on the production and effect of the deadly arrow poison curare, used for warfare and hunting, "[t]he Indian from time to time invited us to taste the liquid; its taste, more or less bitter, decides when the concentration by fire has been carried sufficiently far. There is no danger in this operation, the curare being deleterious only when it comes into immediate contact with the blood" (Humboldt 2019, 4: 196).

Humboldt's numerous texts on Indigenous American cultures encompass short remarks and thorough studies, ranging from a few lines in his diary to chapters in his books. In his oeuvre we sometimes stumble across terms that seem questionable and no longer acceptable in contemporary discourse. For instance, Humboldt mentioned "hordes" (Horden) (Humboldt 2019, 7: 427), "the savage of the Orinoco" (le sauvage de l'Orénoque) and the remains of people "sunken back into barbarism" (replongés dans la barbarie) (Humboldt 1970, 2: 258). Nevertheless, as a result of his research in the field, he developed a critical consciousness of concepts and constructs. In his famous travel report published 1814-1825, he explained to his readers: "I use the concept 'savage' with regret, for it indicates a difference in culture between the subordinated Indian, living in the missions, and the free and independent Indian, that often is refuted by observation" (J'emploie à regret le mot 'sauvage'...) (Humboldt 1970, 1: 460). He continued that the so-called savages in the bush actually lived in villages with chiefs and plantations of bananas, manioc and cotton: 
They are hardly more barbarian as naked Indians in the missions, where they were told to make the sign of the cross. In Europe it is an error quite common to estimate all Indians not subordinated as nomads and hunters. In Tierra Firme agriculture existed long time before the arrival of the Europeans. (ibid.)

According to stadial theories, agriculture was a sign of well-developed societies (Nutz 2009, 163-169). In old age, Humboldt once more underlined his view that "the old Indian population" of South America had increased in numbers due to autonomous conditions. The chief reason was that "many centuries before the Spanish Conquista the population there was made up of peaceful agricultural tribes" (Humboldt 2019, 7: 427). With regard to Humboldt's general appraisal of their societies, the decisive aspect is that he did not strive 'to other' Indigenous Americans as aliens, but highlighted their skills, intelligence and culture. Interestingly, even when elderly Humboldt retained the model of stadial development and progress in history. Yet, he remarked that it was "so vague and often so inadequate" (so unbestimmt und oft so unpassend) to call even less developed tribes "savages (Indios bravos)" (ibid.). During his travels and in his reports on the former territories of the Incas, the Aztecs, the Toltecs and other ethnic groups, he found manifold proof of "nations that [had] reached a form of higher culture" (ibid., 428). In this line he also highlighted paintings, pyramids, giant sculptures and multistorey family homes. Moreover, during the post-1848 years, when in monarchical Germany the political constitution was anything but perfect and in the context of the Kulturkampf tensions between the Protestant state and the Catholic Church, he emphasised the existence of "civic and state institutions" and the dissemination of one and the "same kind of religious cult" in pre-Colombian America (ibid., 429).

Humboldt tried to avoid generalizations and strove for differentiation. He recorded substantial differences between the advanced pre-Colombian societies in the Andes and along the Pacific Coast on the one hand, and the tribal "nation[s]" (la nation) (Humboldt 2003, 181) on the Orinoco and in the Amazon basin on the other. In his essay of 1857, the term "culture" is reserved for the former, while - against his frequently expressed personal views - the latter appeared to be places of "savageness" (Wildheit) (Humboldt 2019, 7: 430). Still, Humboldt was always keen to grasp the sociocultural logic of what at first sight seemed 'savage.' Even Indigenous groups classified as "très-sauvages" - such as the earth-eating Ottomacs in the Orinoco valley were worthy of a thorough unbiased study. The eating habits of "une nation qui mange de la terre" were not labelled 'primitive' but as "la tradition" and "l'usage." Clearly, the Ottomacs' practice of eating loam corresponded to their limited natural environment, more precisely the seasonal shortage of fish and turtles. Moreover, it was not a matter of pure chance, but could be compared with the customs of other ethnic groups in Asia and Africa as a form of adaptation to seasonal changes in their environments (Humboldt 2009, 25, 28).

Humboldt leaves his readers with no doubt about the overall devastating impacts of colonialism that shaped the landscapes he encountered. There is no need to repeat Humboldt's role as a fierce opponent of slavery, racism and exploitation. Towards the end of the voyage on the Orinoco, he concluded in his diary that the Conquista had "even hindered progress of human culture in South America." The fact that he and Bonpland had encountered so many deserted places and "dead silence" (Totenstille) on the banks of the river appeared to him as a direct consequence of warfare and colonial processes of land grabbing, that had forced native Americans to withdraw to remote areas (Fortschritte der menschlichen Kultur in Südamerika noch erschwerter; Europäer (...), die Ihr den Wilden vom Ufer verdrängt; Der Wilde lebt jetzt zurückgedrängt) (Humboldt 2003, 201). Conversely, he praised the industrious trade and cotton manufacturing of the natives in the province of Quito, which reminded him of prosperous European countries like Switzerland and the Netherlands. Yet, he argued, the effects of prosperity could still be increased, if the natives were not "slaves, without freedom, without ownership and without tools!" (Humboldt 2006, 81). Clearly, Humboldt advocated a transformation from an economy of slavery to a property system with free "peasants, leaseholders and proprietors" (que les malheureux esclaves peuvent devenir paysans, fermiers et propriétaires) (Humboldt 1970, 2: 64). This aspect of his argument can be related to the liberal model of society and economy, released and emancipated from the control of princes and other colonial powers. In principle, Humboldt had strong sympathies with the underlying ideas of liberalism, a revolutionary force in the years around 1800 (Raphael 1995). 


\section{Degraded nature, Indigenous perspectives, markets and power relations}

It is well known that in some of his famous accounts of nature, Humboldt tried to bridge the gap between Romanticist ideas of pristine nature - which had just begun to flourish during the time of his travels to America - and scientific discourse. The chief example is his Aspects of Nature, first published in 1808, which has come under attack from post-colonial critics (Pratt 1992, 111-143; cf. the responses of Sachs 2003 and Wulf 2015). However, this criticism has concentrated on a very small sample of his works. With regard to his extremely comprehensive studies, parts of which have only recently been made accessible, the overwhelming experience of 'primordial nature' and the methods of measuring and accuracy offer a less partial view.

In the following, we will focus on the question of whether Humboldt avant la lettre reflected on political ecological issues of the uses of nature. More precisely, did his reports cover the aspects of degradation and sustainability? Did he discuss who the responsible actors were, and how the constructions of these constellations were driven by powerful local groups? Did he include the perspectives of local Indigenous actors in a nonhuman and differentiated ontological view? In spite of Humboldt's overall liberal ideas, were local practices contextualised with regard to power and market relations? Humboldt did have a strong sense of limited access to resources, the influence of powerful actors in particular places, and he recognized societal development issues including who defines hegemonic discourses about American nature. The following cases illustrate these points.

\section{Outlining colonial degradation of a lake ecosystem}

While he stayed in New Granada, Humboldt visited the basin of Lake Valencia, a very fertile region with a savannah-type climate, southwest of Caracas. During the course of the $18^{\text {th }}$ century, the valleys around Lake Valencia had experienced a rapid expansion of agricultural plantations. Owned by members of the white creole elite, the haciendas produced sugar cane, cotton, coffee and cacao for export to European markets, thanks to the exploitation of a non-white slave labour force (Crist and Chardon 1941; Andrews 1985, 109-121; Fisher et al. 1990). The lake, "which the Indians call Tacarigua" and its environment caught Humboldt's attention because over several decades the water level had dropped considerably (Humboldt 1970, 2: 66). The fall of the water level and its causes had already been discussed by the historian José de Oviedo in his history of the province of Venezuela, published in Madrid in 1723, as well as in a geographical report by the local official Antonio Manzano (Relaciones geográficas 1909, 33-43). It could be seen from the course of the shoreline and the new islands that had emerged from the water. However, the causes seemed enigmatic. Locals assumed that the water escaped through a subterranean exit. Humboldt devoted several days of his trip and a longer section of his travel report to the phenomenon. In his analysis he combined geological, climate, agricultural, economic and political aspects. Strikingly, Humboldt's survey in his Relation historique included issues and even used key words of contemporary ecological discourse in the context of an ecological systems analysis, of which feedback loops form a central part. Indeed, the lake was perceived as the centre of "a specific system" (un système particulier; le centre d'un petit système de rivières) of the rivers and creeks of the valley; the "equilibrium" of nature was "disturbed" (l'équilibre est rompu); the "degradation of forests" (la destruction des forêts) for economic reasons had a considerable impact on the quality of the soil of the valley; deforestation had resulted in sudden floods as well as indirect consequences for future generations; reforestation (de nouveau de forêts) seemed to be a suitable means of both preventing increased aridity and of fostering the economically important plantations in the adjacent Aragua valley (Humboldt 1970, 2:65-76). In the interest of the local inhabitants, Humboldt suggested political reforms to enhance prosperity in the valley.

In terms of methods, Humboldt observed not only the water level of the lake but also the nature and the plantations in its direct environment. He consulted historical reports and old chronicles and measured temperatures, distances and air moisture. Not least, he tried to attain local first-hand information by interviewing the inhabitants of the Aragua valley, Indigenous fishermen and local guides. He informed himself about the political system and the administration of the region. Hence, his concluding explanation for the drop of the water level was twofold. First, the continued deforestation of the hills and mountains around the lake for the sake of intensified hacienda agriculture had had devastating consequences: the "[c]olonial agriculture" (l'agriculture coloniale) of the affluent elite (riches propriétaires) had resulted in evaporation, aridity and soil erosion (ibid., 76). Second, the new owners of the basin's sugar cane, indigo and cotton plantations - land that 
had probably been grabbed from Indigenous communities - had built canals to irrigate their crops and thus interrupted the influx of water into the lake (ibid., 72-75). The impending effects of deforestation for future generations were both a lack of water and a lack of firewood. Humboldt explicitly integrated his findings into the wider framework of colonial economy: "The degradation of forests, executed by European colonists everywhere in America with careless hastiness, is leading to the complete ebbing or at least the diminution of sources" (ibid, 72). To ensure development, Humboldt suggested the reforestation of the mountains around Lake Valencia and the Aragua valley. However, he was not blind to the economic potential of agricultural plantations. For him, the ecological risk of continued dehydration of the lake also implied serious economic damage for the economy of the valley in the long run. In this line, he went one step further and criticized the government's mercantilist policy of monopoly and lease (le monopole oppressif de la ferme) for restricting the cultivation of tobacco and thus economic growth in the valleys around Lake Valencia (ibid., 83). Humboldt did not present a class analysis in Marxian terminology, of course. However, it seemed evident to him that in the context of colonial economy, the new landowning class was exploiting environmental resources to an unsustainable degree, in the long term not only undermining economic gains but also destroying basic water supply and forests. These two common-pool resources are today perceived as important elements in the debate regarding sustainable management and are therefore central to the Sustainable Development Goals (SDGs) (see Haller et al. 2018).

In Humboldt's overall analysis of geographical and geological phenomena, the consideration of local or rather Indigenous knowledge could be deemed relevant in diverse ways. Although Humboldt generally remained sceptical of the contents of any legend or myth, he was at the same time fascinated by the stories and myths of Indigenous groups in South America (Eibach 2018; 2019). However, he had to test whether they included nuclei of historical evidence. In particular, the historical experience of increasing or decreasing lake water levels, floods and peculiar courses of rivers had inspired Indigenous interpretations. To Humboldt, a local "geological myth" (geognostische Mythe) was of interest in itself and worth mentioning alongside to his empirical results: "The plateau, Llanura de Bogota, which according to the myths of the native tribe of the Muiscas, is the ground of the desiccated lake Funzha, has the medium height of 8,130 feet" (Humboldt 2019, 5: 441). In the heyday of European intellectuals' fascination for Ancient Greek philosophy and civilisation, he ennobled the myths of the Muiscas, an ethnic group in the Colombian Andes, by comparing them with Greek mythology. Like the Ancient Greeks, the Muiscas as well as the Incas perceived gods, demigods and mythical founders of human society. Thus, "[t]he local flood, emergence and rising water stage of Lake Funzha was caused by a female figure, called Huythaca, hostile to the Heliad [Bochica]" (ibid., 442). Myths of this kind led Humboldt to a side glance regarding the significance of mythical founders in different cultures across the globe (ibid.). Such digressions had little in common with the classical methods of natural sciences, but they shed light on Humboldt's sincere interest in what could be called the construction of Indigenous theory. Apart from that, faith in unproven myths did not solely appear as a feature of native tribes. The story of the land of gold, El Dorado, purportedly situated at the legendary Lake Parime - another myth that had circulated among the Muiscas and other native "powerful nations" of the Andes - had over the centuries triggered a number of fruitless Spanish and English expeditions. Humboldt speculated that Indigenous actors had used the story of El Dorado, whose location "similar to the myths of antiquity" could be altered and adapted, deliberately to disorient the unwelcome Spaniards (Humboldt 2019, 5: 266). Thus, here we also have a political ecology perspective of the second type, with the observation that all actors involved are pursuing discursive strategies in a political context.

\section{Local resource governance, ontological views and institutional change}

In several ways, Indigenous American societies with limited resources had to deal with the problem of exploitation and degradation of nature. Through studying Humboldt's texts, can we decipher the specific logics or institutions that safeguarded sustainability? An interesting case study is Humboldt's report of 'the Great Cavern of the Guacharo' in the valley of Caripe in present-day Venezuela. Humboldt and Bonpland entered the cavern, known for its nocturnal birds, on 18 September 1799, accompanied by "Indian magistrates" and several monks from a nearby convent (Humboldt 2009, 35). Humboldt, the former Prussian mining engineer who had explored the caverns of Central Europe, must have been thrilled by the opportunity to research the enormous 
Cueva del Guácharo. Stretched across ten kilometres along a subterranean river, it is the largest stalactite cave in South America. His report again combined scientific accuracy with the aesthetics of the sublime: "The aspect of this spot is majestic even to the eye of a traveller accustomed to the picturesque scenes of the higher Alps." (ibid., 36) Although Humboldt was primarily interested in the geology and the fauna of the cavern, he noted that its property rights were disputed between "the members of an Indian family" and "monastic institutions" (ibid., 40). He discerned a general problem - nota bene in America as well as in Europe - and continued: "It would seem natural, that the produce of the chace [chase] should belong to those who hunt: but in the forests of the New World, as in the centre of European cultivation, public right is modified according to the relations which are established between the strong and the weak, the victors and the vanquished" (ibid.). In addition, he recorded the economic exploitation of the cavern by the local natives and the problems of communicating with his guides. In spite of hundreds of guacharo birds hovering around their heads and exclaiming loudly in the dark, he wanted to proceed into the inner parts of the cavern as far as he could. At a certain point the native guides refused to go on: "We had great difficulty in persuading the Indians to pass beyond the outer part of the grotto" (ibid., p. 41). As the cries of the birds became shriller, even the missionaries' authority did not suffice to persuade the guides to advance further into the dark. Humboldt must have left the cavern somewhat dissatisfied. The reason for the natives' refusal to continue "our progress" (ibid.) was evident, and in terms of understanding Indigenous cultures, absolutely worth noting: "The natives connect mystic ideas with this cave, inhabited by nocturnal birds; they believe, that the souls of their ancestors sojourn in the deep recesses of the cavern. (...) To go and join the guacharos, is to rejoin their fathers, is to die" (ibid.).

This was not yet the whole story. Humboldt went on to outline the economic importance of the cavern with its population of nocturnal birds. Melted in pots, the rich fat pad of the young guacharo birds could be used to produce high-quality butter or oil. According to Humboldt, once every year the natives entered the front part of the cavern with long poles to kill thousands of young birds. At this time of "the oil harvest", the natives built huts with palm leaves at the cavern's entrance to immediately refine the birds' precious fat (ibid., 39). Moreover, "[t]he magicians and the poisoners perform their nocturnal tricks at the entrance of the cavern, to conjure the chief of the evil spirits" (ibid., 41-42). Humboldt concluded that the unique population of birds was primarily fostered by superstitious beliefs. In terms of political ecology, he noticed the sustainable ecological outcome of this specific institutional design: "The race of the guacharos would have been long ago extinct, had not several circumstances contributed to its preservation." He assumed that the birds also had nests in neighbouring, narrower caverns. However, more importantly, "[t]he natives, restrained by their superstitious ideas, have seldom the courage to penetrate far into the grotto." He was assured by the missionaries "that hitherto no sensible diminution of the birds had been observed" (ibid., 40).

The ritualised practice of a harvest once a year was also observed in the case of the cosecha of turtle eggs on Boca de la Tortuga, an island in the middle of the Orinoco River. When Humboldt and Bonpland disembarked from their canoe, they were surprised to find a camp of more than 300 people, most of whom were natives of different tribes: Guamos, Ottomacs and Caribs. Also present were several white traders from Angostura (quelques hommes blancs, surtout (...) petits marchands) who wanted to purchase cheap turtle egg oil from the natives. Humboldt additionally met a distrustful Franciscan missionary of the Uruana mission who claimed to have come to the island to establish order among the natives and to celebrate Mass with them every morning. At the same time he wanted to receive oil for his convent. According to Humboldt, in spite of the missionaries' claim to power, the natives of the Uruana mission regarded the island of South American river turtles as their common property (comme leur proprieté). The assembly of sellers and traders reminded him of the famous fairs in Frankfurt and Beaucaire in Europe. Evidently, the purpose of the gathering was the upcoming Pesca de Tortugas (Humboldt 1970, 2:240; see also 240-250). Every March, thousands of turtles from the Orinoco River beached on a number of islands to entrench millions of eggs in the sand. The cosecha always started by the end of March or early April. The natives excavated as many eggs as possible and, as in the case of the 'oil harvest' of the guacharo cavern, immediately refined it by cooking their precious oil on the spot. These are examples of a collective use arrangement of resources or commons, an important topic in the study of sustainable resource management, with sustainability in a political ecology or institutional context deriving from ritualised actions that coordinate the time and the intensity of use and distribution of common-pool 
resources owned by common property institutions. This also resembles the theory of optimal or sustainable foraging in studies of hunter-gatherer societies (Haller 2010, 2013).

A political ecology analysis can also be discerned when Humboldt was attentive to the natives' knowledge, and to the institutional change occurring in the area. Indeed, by the time of Humboldt's trip on the Orinoco, the missionaries had installed their regime over the harvest. Humboldt praised the former regime of the Jesuits in contrast to that of the Franciscans who had by now succeeded them in the missions of the Orinoco area (Humboldt 1970, 245). In any case, the purpose of the changing regimes was based on the missionary conservation discourse to avoid Indigenous overfishing, or rather overharvesting and extinction. The Jesuits had declared one stretch of the beach a reservation zone, not open for the annual cosecha. The Franciscans, namely the Franciscan missionary Humboldt met on the island, had appointed a representative. His job was to distribute spots on the beaches by lot to the tribal groups involved. According to Humboldt, the natives who participated in the harvest of turtle eggs were mainly "Indians of the Missions", so-called "reducidos et neofitos", who had been taught to follow the orders of the missionaries in a superficial and quasi-mechanical way (ibid., 246). Overall, the new regime of the Franciscans seemed to have had a devastating effect, for the whole shore was recklessly dug over: "One already has the impression that the harvest is getting less profitable from year to year" (Aujourd'hui on fouille toute la plage sans reserve. Aussi croit-on s'apercevoir que les récoltes sont d'année en année moins productives) (Ibid., p. 245).

Humboldt remarked that the old practice of the natives was unproductive. However, his report also suggested that an older regime of sustainability that by ecological standards had worked well was being replaced by a new unstable one with questionable effects. The natives had set up guards to protect the turtles on the beaches against arriving boats, and the attacks of jaguars and crocodiles. In both economic and ecological terms, their procedures were not ideal. Yet, despite the use of awkward methods, in particular the inadvertent destruction of numerous eggs, the old ways of hunting the turtles and harvesting their eggs had caused no serious damage to the species. On the contrary, "before the missionaries arrived at the banks of the river, the natives exploited a product, here supplied by nature in such abundance, to a much lesser degree" (ibid., 245).

It is worth considering the French and the German versions of this conclusion. Humboldt's report was first published in French in the Relation historique, where it says: «Avant l'arrivée des missionnaires sur les bords du fleuve, les indigènes profitoint beaucoup moins d'une production que la nature y a déposée en si grande abondance» (ibid.). In the German edition, published with the consent of Humboldt in 1859-1860, this text passage was more explicit: "Ehe die Missionäre an den Fluß kamen, beuteten die Eingeborenen ein Produkt, das die Natur hier in so reicher Fülle bietet, in weit geringerem Maße aus." (Humboldt 1860, 3: 53; cf. Humboldt 1991, 2: 823; 1606). The German verb ausbeuten (beuteten...aus) has a more negative sense than the French verb profiter. Its semantics relates closely to the English verb 'to exploit.' Thus, Humboldt observed, under the old native's regime, nature was less exploited. He recognised institutional changes and understood how the Indigenous peoples managed the turtles and their eggs as a common property, rather than the centralized (mis)management by the missionaries. Humboldt continued to examine the relevance of the turtles and the refined oil for the nourishment of the natives and for local markets. He figured that the traders took no less than seventy or eighty per cent of the profit from the egg oil (Humboldt 1970, 248). However, the Indigenous natives who participated in the cosecha as well as others also used the opportunity to supply themselves and their families with turtles and eggs (ibid., 250).

It was the issue of guano (bird or bat droppings rich in nitrogen, phosphate, and potassium) that stimulated Humboldt to argue more explicitly for an elaborate Indigenous regime of sustainability, and to identify risks of exploitation of the local economy. This may seem surprising, as it is a well-known fact that Humboldt himself first brought guano to Europe and thus triggered the $19^{\text {th }}$-century globalization of its use as an agricultural fertiliser. During his stop in Lima, he had managed to acquire samples of guano from the three Chincha Islands, twenty-one kilometres off the Peruvian coast (Rott 2016). In 1806, after his return to Europe, Humboldt had offered the samples to leading chemists in Paris and Berlin. Their examinations had revealed high concentrations of phosphorus and nitrogen and thus excellent effects on soil fertility. However, it was not until the 1840s that the import of guano from Peru fuelled an unforeseen major boom. The shipments of guano from Peru gave European agriculture, which at this time was being forced to cope with rapid population growth, a veritable boost. Moreover, these exports pumped large sums of money into Peru. In the long run, however, 
the export of vast amounts of guano, exploited by Chinese migrant workers on the islands under slavery conditions, created severe problems. The Peruvian economy increasingly relied on the export of guano as its chief source of income. Guano became a matter of heavy speculation. In 1879-1884 the competition over exports of fertilisers to European markets even became grounds for war between Peru, Chile and Bolivia. Ultimately, the aftermath of the boom years in the late $19^{\text {th }}$ century saw the collapse of the Peruvian economy.

Humboldt had died long before these events. In his later years, he was still proud to have recommended guano's "employment in fertilising the fields of Europe" (Humboldt 2019, 7: 184). An early liberal, he optimistically expected that the abolition of trade barriers and an increase in global trade would create overall progress and prosperity. Seen from today's perspective, this might seem naïve. However, we must carefully distinguish between liberalism as the legitimate heir of the Enlightenment, today's neoliberal ideas, and the leading ideology of emancipation in the context of ancien régime-type monarchical states that still existed during the first half of the $19^{\text {th }}$ century. Humboldt's statements on guano shed light on traditional forms of preservation, and raised the question of future opportunities for the local population. As early as 1805, Humboldt delineated his views in chemistry journals on the usage of Peruvian guano for local agriculture. He assumed that the feasibility of agriculture on Peru's Pacific shoreline rested entirely on this precious source of minerals, and that guano had been used as a fertiliser in Peru as early as the $12^{\text {th }}$ or $13^{\text {th }}$ centuries, thus before the arrival of the Spaniards (Humboldt 2007, 320-323; 2019, 2: 408-412).

Humboldt himself had not visited the so-called Guano Islands. He was amazed by the enormous number of birds necessary to generate the amount of bird droppings for fertilisation across wide areas. In the area around Arica, according to his report, the soil around every plant was fertilised three times per year. Therefore, the question emerged of how the Incas had managed to utilise guano sustainably over centuries without overexploiting it, as later occurred under early capitalism. In contrast to the Orinoco region, the territories of the Incas had state-like institutions: "Under the government of the Incas, guano was regarded a relevant object of state economy. It was banned under threat of death penalty to kill the young birds on the Guano Islands. Each island was given an inspector, each one was divided into certain provinces." Only with regard to "these provisions" (aus dieser Vorsorge) could one understand the remarkable increase of guano over long time periods. However, comparable with his findings on the Boca de la Tortuga, the old administration in the region, which evidently had ensured sustainability, had been turned upside down. Succinctly, Humboldt noted: "All of this nice order has been overthrown. Now, one digs at every time of the year." He clearly recognised the dangers of over-usage and exploitation, in particular for the local economy. "What", Humboldt asked rather sceptically, "will be the effect for Peruvian agriculture, and the population at the coast, when the Guano Islands will be exhausted?" (Humboldt 2007, 321-322). Nevertheless, he seemed to assert the potential For the use of guano in Europe more strongly. It is likely that because he was a man with an $18^{\text {th }}$-century background, he underestimated the enormous global power of capitalism, yet to arrive during his lifetime.

\section{Discussion}

Humboldt's unique systemic perspective on historical and environmental contexts was one of the outstanding feature of his work. It illustrated his ability to perceive everything he discovered in interrelated terms. This led him to shift his view from simply focusing on geology or botany, to a holistic picture. Moreover, he realised that humans have been a transformative species. However, what made him interesting with regard to the pioneering ideas of political ecology was the fact that he included power relations between humans into his analysis. We argue that in this regard, Humboldt was a founding figure of a political ecology way of thinking - rather than a school of thought - rendering him way ahead of his time and still serving as an inspiration today. Indeed, it is not that he simply related environmental issues to political and economic structures, but that his thinking anticipated the new directions of political ecology (see also Haller 2019), specifically by perceiving changes in the environment and contextualising the colonial and power perspectives shaping these changes, while integrating systematic and feedback-related outcomes driven by powerful actors in the areas he researched. According to this view, the areas that he visited were not devoid of people because they seemed 'pure' and 'untouched nature.' Rather, Humboldt realised that these environments were empty because Indigenous peoples had been evicted. In the examples delineated above, 'nature' is not 'pure nature', but rather 
cultural landscapes, developed before colonial times. Resources such as water, turtle eggs and guano were not under local threat - given that otherwise they would have been evicted or overused a long time ago - but were there because they were managed by local institutions. Traditional local management was responsible for the sustainable use of these resources and conversely their dismantling via the colonial system was responsible for their unsustainable governance and overuse.

On the one hand Humboldt was a liberal of his time. He hoped for - in a rather naïve way - balanced, power-specific relationships in a fair market system beneficial for all and not just for elites. On the other hand and in contradistinction to his liberal thinking, his analysis already contained several relevant aspects of what would much later become a political ecology view, in a sense interlinking Marxian and Foucauldian strands of political ecology: exploitation and hegemonic governmentality are evident. Nevertheless, the issue that is debated today under the label of the ontological turn of political ecology was also present: Humboldt was interested in Indigenous views and non-human perspectives towards the environment, which he again understood as a co-production of local people viewing themselves in connection with their living and spiritual environment. By contrast, many of Humboldt's peers as well as contemporary conservationists deny that humans have been positive agents of transformation and have created cultural landscapes of which they have a wide knowledge. Humboldt's work also directs our attention to the fact that Indigenous peoples have crafted institutions for sustainable management, often including religious or spiritual views. In addition, his readiness to acknowledge local institution-building was political in a sense, as it provided these people with a legitimate claim to their landscapes, something he explicitly advocated.

We have highlighted three elements of this thinking that embody relevant aspects of political ecology and these are clearly related to the connections between ecology and power. First, Humboldt respected Indigenous culture in so far as he was interested in explaining these peoples' views as equally legitimate to others, within an environment of which they possessed comprehensive ecological knowledge and were part of the environmental interrelations at play (Wechselwirkungen). He did not regard their views as primitive but different, and they were perceived as noble savages - but as other knowledgeable humans. Nevertheless, this interrelation was undermined by the colonial process that evicted and disgraced local people. Accepting equality despite differences in the management of the environment is a key finding of political ecology, especially in the context of modernisation and neoliberal economic development paradigms that political ecology criticises. Despite his early liberal views, advocating wide-ranging political reforms to avoid revolution, Humboldt never lost sight of power asymmetries leading to relations of subordination, repression and exploitation. In this sense he may be seen as a forerunner of a Marxian stance of political ecology.

Second, he was attentive to how the colonial and early capitalist system pushed away local native land users and their environmental perspectives, and how this process contributed to an unsustainable use of resources. Thus, his critical view on the environment did not correspond with ideologies of wilderness. Environmental degradation was not seen as simply a natural phenomenon (e.g. the reduction of water in Lake Valencia), as shown in some critical avant la lettre constructivist strands of political ecology ${ }^{2}$ that focus on discourses of pure nature. Indeed, the scarcity of water is not seen as natural, but as the outcome of colonial market-oriented transformations of the environment via the powerful plantation economy of colonial elites. At the same time, he was interested in Indigenous theories and explanations, discourses that could be used strategically and that constructed powerful myths. An example was the myth of El Dorado, which Humboldt took as an Indigenous strategy to mislead the Spaniards because of their greed for gold.

Finally, Humboldt examined local resource governance systems and how these were embedded in practical needs and in local ontologies. He was additionally interested in how these were integrated in the local institutional design of governance arrangements. He analysed how institutional change implemented by missionaries and colonial powers undermined local practices, which had - in his view - been more sustainable than under the new order. This focus on local governance systems is closely related to the debate about the role that common property institutions play in the sustainable management of common-pool resources such as wildlife (specifically guacharo birds, turtles and other birds providing dung for fertilization). In these contexts, he showed how local common property institutions led to sustainable outcomes because embedded in religious

\footnotetext{
${ }^{2}$ For constructivist strands influenced by Foucault, see Haller (2019).
} 
belief systems of taboo (birds in the guacharo cave), collective use rules (turtle eggs), and institutional restrictions by an Indigenous state (the use of guano and the protection of the bird population). In contrast the new rules that accompanied missionaries and the capitalist market, on which the new state of Peru depended, undermined Indigenous institutions and their sustainable use of the commons. Integration into world markets could even lead to violent conflicts and warfare. What Humboldt called a 'nice old order' was in fact from a political ecology perspective a variety of locally established institutional designs that led to the sustainable use of these resources. Its change - meaning the undermining of these rules - could obviously lead to unsustainable use. Therefore, Humboldt provided an early attempt to critique a view that later became the 'tragedy of the commons' paradigm, as additionally critiqued in political ecology from Marxian perspectives (against enclosure) and Foucauldian ones (showing how a discourse of economic rational governmentality by the state undermined local sustainable use). Furthermore, the non-human ontological turn found in contemporary political ecology was present in some of Humboldt 's thinking. This was illustrated by his interest in how religious belief systems and emic views on the interaction between humans and so-called nature are part of the institutional design, an idea discussed in more recent debates on the management of the commons (Berkes 1999; Haller 2010, 2013, 2019).

\section{Conclusion}

Was Alexander von Humboldt the unknown founder of political ecology? This is - as we argue - perhaps an overly bold claim. Nevertheless, Humboldt included in his holistic views numerous perspectives that address fundamental aspects of a political ecology of the environment. Indeed, his perspective is historic, pays attention to all views, incorporates local Indigenous ontologies and ecological knowledge, addresses environmental outcomes based on power relations that are manifest in colonial land grabbing and exploitation processes, looks at discourses of governmentality and market rationality, and underlines the view that local knowledge and rules have to be taken seriously. Humboldt demonstrated how colonial institutional change (alterations to property rights, resource governance rules and discrimination or exclusion of the previous inhabitants of the continent, as well as slavery) led to environmental degradation. This represented a genuine political ecology perspective, created over a century before the term came into existence. For Humboldt, interconnectedness was not just an issue for natural scientists to explore, but a historical, political, cultural process laden with power. Local ways of using the environment resulted in cultural landscapes and sustainable common resource management institutions that were increasingly undermined or altered as a new order replaced the old. As a legacy of Humboldt's work, we can profit from his differentiated 'institutional political ecology view' in order to understand how ecology and power are interrelated.

\section{References}

Andrews, G.R. 1985. Spanish American independence: A structural analysis. Latin American Perspectives 12(1): 105-132.

Berkes, F. 1999. Sacred ecology: Traditional ecological knowledge, and resource management. Philadelphia: Taylor \& Francis.

Blaikie P.M. and H.C. Brookfield (eds.). 1987. Land degradation and society. London: Routledge.

Bunzl, M. 1996. Franz Boas and the Humboldtian tradition: from volksgeist and nationalcharakter to an anthropological concept of culture. In G.W. Stocking Jr. (ed.). Volksgeist as method and ethic: Essays on Boasian ethnography and the German anthropological tradition. Madison: University of Wisconsin Press. Pp. 17-78.

Brockington, D., R. Duffy, and J. Igoe (eds.). 2008. Nature unbound: Conservation, capitalism and the future of protected areas. London: Routledge.

Crist, R.E. and C.E. Chardon. 1941. Changing patterns of land use in the Valencia Lake basin of Venezuela. Geographical Review 31(3): 430-443.

Descola, P. 2013. Beyond nature and culture. Chicago: University of Chicago Press. 
Dettelbach, M. 1996. Humboldtian science. In Jardine, N., J.A. Secord, and E.C. Spar (eds.). Cultures of natural history. Cambridge: Cambridge University Press. Pp. 286-304.

Eibach, J. 2018. Tasten und Testen: Alexander von Humboldt im Urwald. In Eibach, J. and C. Opitz-Belakhal (eds.). Zwischen Kulturen: Mittler und Grenzgänger vom 17. bis 19. Jahrhundert, 141-164. Hannover: Wehrhahn. Pp. 286-304.

Eibach, J. 2019. Geschichte und Geschichten. In Lubrich, O. and T. Nehrlich (eds.). Alexander von Humboldt, Sämtliche Schriften, vol. X: Durchquerungen Forschung. Munich: dtv. Pp. 464-486.

Escobar, A. 1999. After nature: steps to an antiessentialist political ecology. Current Anthropology 40(1): 1-30. Ette, O. 2009. Alexander von Humboldt und die Globalisierung: Das Mobile des Wissens. Frankfurt: Insel.

Fairhead, J. and M. Leach.1996. Misreading the African landscape: Society and ecology in a forest-savannah mosaic. Cambridge: Cambridge University Press.

Fisher, J.R., A.J. Kuethe, and A. McFarlane (eds.). 1990. Reform and insurrection in Bourbon New Granada and Peru. Baton Rouge: Louisiana State University Press.

Haller, T. (ed.). 2010. Disputing the floodplains: Institutional change and the politics of resource management in African wetlands. Leiden: Brill.

Haller, T. 2013. The contested floodplain: Institutional change of the commons in the Kafue Flats, Zambia. Lanham: Lexington Books.

Haller. T. 2018. Paradigm change or old wine in new bottles? Debating and reformulating SDGs - An experiment. Bern: Institute of Social Anthropology.

Haller, T. 2019. Towards a new institutional political ecology: how to marry external effects, institutional change and the role of power and ideology in Commons Studies. In Haller, T., T. Breu, T. de Moor, C. Rohr, and H. Znoj (eds.). The commons in a glocal world: Global connections and local responses. London: Routledge. Pp. 90-120.

Haller, T. and Galvin, M. 2011. Challenges for participatory conservation in times of global change: lessons from a comparative analysis and new developments. In Wiesmann, U. and H. Hurni (eds.). Research for sustainable development: Foundations, experiences, and perspectives. Bern: Geographica Bernensia.

Humboldt, A.v. 1860. Reise in die Aequinoctial-Gegenden des neuen Continents, Hauff, H. (trans.). Frankfurt and Leipzig: Cotta.

Humboldt, A.v. 1970. Relation historique du voyage aux régions équinoxiales du nouveau continent [Paris 1814-1825]. Beck, O. (ed.). Stuttgart: Brockhaus.

Humboldt, A.v. 1991. Reise in die Äquinoktial-Gegenden des Neuen Kontinents. Ette, O. (ed.). Frankfurt and Leipzig: Insel.

Humboldt, A.v. 2003. Lateinamerika am Vorabend der Unabhängigkeitsrevolution, 3rd ed. Faak, M. (ed.). Berlin: Akademie Verlag.

Humboldt, A.v. 2006. Über einen Versuch den Gipfel des Chimborazo zu ersteigen. Lubrich, O. and O. Ette (eds.), Frankfurt: Eichborn.

Humboldt, A.v. 2007. Alexander von Humboldt - Samuel Heinrich Spiker: Briefwechsel. Schwarz, I. (ed.). Berlin: Akademie Verlag.

Humboldt, A. v. 2009. Alexander von Humboldt, Über die Urvölker von Amerika und die Denkmähler welche von ihnen übrig geblieben sind. O. Lubrich (ed.). Hannover: Wehrhahn.

Humboldt, A. v. 2019. Alexander von Humboldt, Sämtliche Schriften. Lubrich, O. and T. Nehrlich (eds.). Munich: dtv.

Kviat Bloch, S., O. Lubrich and H. Steinke (eds.). 2021. Alexander von Humboldt: Wissenschaften zusammendenken. Bern: Haupt.

Lubrich, O. 2009. Stufen, Keime, Licht. Alexander von Humboldt als Ethnograph und Anthropologe. In O. Lubrich. (ed). Alexander von Humboldt: Über die Urvölker von Amerika und die Denkmähler welche von ihnen übrig geblieben sind. Anthropologische und ethnographische schriften. Hannover: Wehrhahn. Pp. 167-190. 
Lubrich, O. 2019. Feldforschung und Ethnographie. In Lubrich, O. and T. Nehrlich (eds.). Alexander von Humboldt, Sämtliche Schriften, vol. X: Durchquerungen Forschung. Munich: dtv. Pp. 437-462.

Nutz, T. 2009. Varietäten des Menschengeschlechts: Die Wissenschaften vom Menschen in der Zeit der Aufklärung. Cologne: Böhlau.

Pratt, M. L. 1992. Imperial eyes: Travel writing and transculturation. London: Routledge.

Raphael, L. 1995. Freiheit und Wohlstand der Nationen. Alexander von Humboldts Analysen der politischen Zustände Amerikas und das politische Denken seiner Zeit. Historische Zeitschrift 260: 749-776. https://doi.org/10.1524/hzhz.1995.260.jg.749

Relaciones geográficas. 1909. Relaciones geográficas de la gobernación de Venezuela (1767-68). Madrid.

Robbins, P. 2004. Political ecology: A critical introduction. Oxford: Blackwell.

Rott, B. 2016. Alexander von Humboldt brachte Guano nach Europa - mit ungeahnten globalen Folgen. Humboldt im Netz. International Review for Humboldt Studies 17(32): 82-109.

Sachs, A. 2003. The ultimate "Other": post-colonialism and Alexander von Humboldt's ecological relationship with nature. History and Theory 42(4): 111-135.

Sachs, A. 2006. The Humboldt Current: nineteenth-century exploration and the roots of American environmentalism. New York: Viking.

Svarstad, H., T. A. Benjaminsen, and R. Overå. 2018. Power theories in political ecology. Journal of Political Ecology 25(1): 350-363.

Wulf, A. 2015. The invention of nature: The adventures of Alexander von Humboldt, the lost hero of science. London: John Murray.

Zimmerer, K.S. and T.J. Bassett (eds.). 2003. Political ecology: An integrative approach to Geography and Environment-Development Studies. New York: Guilford Press. 